\title{
Work and family over the life course. A typology of French long-lasting couples using optimal matching
}

\author{
Ariane Pailhé, Ined, Paris, France \\ pailhe@ined.fr \\ Nicolas Robette, Université Versailles-St-Quentin and Ined, Paris, France \\ Anne Solaz, Ined, Paris, France
}

(Received March 2013 Revised August 2013)

doi:10.14301/Ilcs.v4i3.250

\section{Abstract}

Decisions regarding the division of labour are part of a dynamic process of negotiation between partners and thus develop throughout the life cycle, in relation to family events such as successive childbirths. This article investigates the degree of interaction between work and family of both partners in the long run over the life course. Using an innovative methodology, optimal matching analysis, and data from the French Family and Employers Survey (2004-05), it defines a typology of work-family strategies for about 950 long-lasting couples observed from 3 years before couple formation to 18 years later, and identifies related key life-course stages. Finally, it analyses the factors leading to the various trajectories, and assesses whether preferences or opportunities and constraints greatly influence couples' profiles. Results bring to light a wide variety of work-family patterns, where the number of children and the woman's employment trajectory are the key determinants of these couple profiles. In spite of the trend towards equal opportunities, only women adapt their work patterns, except in the most "work-oriented couples". They use several strategies, by adjusting sequence and timing of births. In line with the standard human capital approach, partners' initial relative endowments influence couples' histories. A more traditional division of work is observed among less educated men and women, while women with greater human capital are more likely to remain employed through the transition to parenthood, whatever their partner's level of education.

Keywords: Work, family, couples, gender, life course, sequence analysis, optimal matching

\section{Introduction}

There has been a marked decline over decades in the degree to which men and women specialise in distinct economic activities. The couple model with male breadwinner is being replaced by the dual earner model in most developed countries (Blossfeld \& Drobnic, 2001). However, childbirths remain a crucial stage in work division within couples. They often imply a re-setting of gender relations within the family, new trade-offs for spouses between career and family life and, often, a modification of the gender division of labour within and outside the family. The gender gap in the allocation of time usually increases after childbirth and with the number of children (Pailhé \& Solaz, 2006; Bonke, Deding, Lausten \& Stratton, 2008), with women devoting more time to housework and parental activities and men to market work (Van 
der Lippe, 1994; Fine-Davis, Fagnani, Giovannini, Hojgaard, \& Clarke, 2004; Regnier-Loillier, 2009).

Decisions regarding the division of labour are therefore not static; they are part of a dynamic process of negotiation between partners (Jansen \& Liefbroer, 2006). Couples adapt their work-family strategies to their life stage (Becker \& Moen, 1999; Anxo, Mencarini, Pailhé, Solaz, Tanturri et al., 2011), and the birth of a child is a key stage. For this reason, most studies analyse employment transitions after childbearing, generally at parity one. These studies focus on a particular moment of the life cycle and do not link the labour market consequences of the various demographic events, e.g. couple formation or subsequent childbirths. Nor do they account for the fluidity of employment status, i.e. movements into and out of the labour force, for many parents along the life course (Hynes $\&$ Clarkberg, 2005). Moreover, they focus on one direction of the shift, usually from family to work, i.e. the consequences of childbearing for labour market participation. Thus the reverse relationship, i.e. strategies dealing with childbearing decision and the timing of fertility as a result of employment opportunities, are rarely taken into account, although some couples may reduce the number of children they have or postpone childbearing decisions, during economic uncertainty on the labour market (Matysiak \& Vignoli, 2009; Pailhé \& Solaz, 2012).

Furthermore, little research has been devoted to describing these various strategies regarding work and family using both a longitudinal and a couple perspectives. Usually, studies linking professional careers and family histories adopt an individual point of view, often the female's, since women bear the main part of post-birth adjustments (GutiérrezDomènech, 2005; Del Bocca, Pasqua \& Pronzato, 2009; Fouarge, Manzoni, Muffels \& Luijkx, 2010). With the generalisation of the dual-earner couple model, male and female working patterns are increasingly inter-dependent. Since male and female labour participation decisions are made jointly, couples rather than individuals should be used as analytical units (Becker \& Moen, 1999; Blossfeld \& Drobnic, 2001).

This article investigates the degree of interaction between work and family of both partners in the long run across the life course, without assuming a direction of causality. It analyses the diversity of couples' work-family strategies, and identifies related key life course stages for long-lasting couples, i.e. couples in partnership for at least 15 years. Finally, it analyses the factors leading to the various trajectories, and assesses whether preferences or opportunities and constraints greatly influence couples' profiles.

Both the lack of adequate data and the limitations of standard quantitative techniques explain the scarcity of studies on couple trajectories. Hence, few longitudinal sociodemographic surveys interview both partners. Getting information on the partner from the respondent, limits retrospective inquiries and potentially biases the data due to the lack of accuracy and the specific position of the respondent. The second problem is technical and is related to the methods that can be used to analyse data at a couple level. As fertility and work choices may be highly inter-dependent, using standard regression models has generally failed because they necessarily make an a priori choice of direction of causality, i.e. family to work, or work to family. For this reason, they are both theoretically limited and statistically biased. Additional econometric techniques may be used to solve endogeneity problems, but finding an appropriate instrumental variable, that explains work outcomes and not family ones, remains difficult. Another challenge is taking into account the many transitions which compose the unfolding life course.

This article overcomes these methodological difficulties. First, the French "Enquête Familles et Employeurs" collected by INED (Institut National d'Etudes Démographiques) in 2004-2005 provides retrospective employment and family histories for each partner. These longitudinal data can be used to link family dynamics with employment trajectories. Second, it uses an innovative methodology to describe the work and family histories of both partners, without making any causal assumption about the relationship between family and work, or between a partner's characteristics and the other's behaviour. Sequence analysis, and more specifically optimal matching analysis, is used to examine the diverse ways that couples balance work and family in the long run.

\section{Background}

Two potential mechanisms may affect couples' work-family strategies. According to the standard neoclassical economic theory, women are assumed 
to work for pay if the opportunity cost of working in the market is lower than the opportunity cost of staying at home (Becker, 1965). Women with higher human capital are more likely to remain at work across the life cycle, because they have a higher opportunity cost if they stop working. The presence of children is assumed to decrease female labourforce participation because it raises the value of women's time at home. The number of children has two opposite effects. On the one hand, the need for care-giving increases with the number of children, and home productivity is higher. On the other hand, financial needs increase with the number of children, so there is more need for the woman's income. The age of children is also important: as children grow older they require less supervision but more financial expenditure, which decreases the value of a woman's time spent at home. The impact of children on career path concerns the partner who invests in home production, either the man or woman in theory, but is usually studied from the female point of view.

At the couple level, spouses are assumed to specialise in market work and domestic production according to their comparative advantage. Women are supposed to have a comparative advantage in domestic work, as they often earn less on average than their husbands for many reasons. A more recent and growing body of the literature on the female labour supply is moving away from this human capital model. These alternative economic models dealing with household decision-making processes and strategic interactions between spouses have given an alternative explanation of labour supply (Chiappori, 1988). In that framework, each spouse maximises their own welfare, and takes into account their current and future bargaining position in the decision to participate in the labour force or not. The individual bargaining positions depend on relative spouse resources such as age, income, level of education and occupational position.

The sociological literature rather emphasises the influence of norms and gender roles in explaining the division of labour between spouses. It argues that, despite women's massive entry into the labour force, men and women often play different roles in their partnerships. For instance, according to the "doing gender" approach, the greater involvement of women in housework and of men in market work, is a way of reaffirming their gender identities
(Goffman, 1977). Work can be seen as an instrument enabling men to exercise their role as providers, and housework as an instrument enabling women to exercise their role as family carers. This relationship of dependency in the couple is in line with normative expectations. The strong social pressure that allocates child rearing to women and disapproves of working mothers explains the negative effect of children on the female labour supply (Shelton \& John, 1996). This specialisation of women in child-rearing tasks is explained in "role theory" by the substantial social rewards they receive when they participate in mothering, whereas men receive far fewer such rewards for fathering (Van der Lippe, 1994).

Conversely, preference theory focuses on lifestyle preferences as a predictor of women's choices regarding fertility and employment patterns (Hakim, 2003). This theory emphasises the heterogeneity of women in each country and distinguishes three ideal-types of women, based on preferences related to combinations of market work and family work: they are home-centred, work-centred, or adaptive women. Adaptive women, who are the majority, combine employment and family work without giving priority to either, and often opt for part-time work after childbearing. Work-centred women prioritise their jobs and many remain childless, while homecentred women are focused on family life and avoid market work as long as economically possible.

Considerable empirical research using crosssectional data shows that the current employment statuses of both partners and the fact of having children both play a role in the household division of labour (Craig \& Killian, 2010). Fewer studies focus on women's life courses, and even fewer on men's (Ravanera, Rajulton, Burch \& Le Bourdais, 2002). However, the timing and sequence of events are important. Indeed, the timing of parenthood is affected by the position of both partners in the labour market, especially the stability of contracts (Vignoli, Drefahl \& De Santis, 2012). Similarly, the timing of marriage plays a role in the division of household labour: the amount of housework is lower for men and women who entered marriage at a later age (Pittman \& Blanchard, 1996). Parenthood transition has also a significant effect on women's housework, while there are no effects on men's (Gupta, 1999; Baxter, Hewitt \& Haynes, 2008). Most studies examine the short-term effects 
of parenthood, mainly due to limited data. However, two recent studies show that it has longterm effects. This highly gendered division of labour caused by parenthood continues more than 10 years after childbirth in Germany (Kühhirt, 2012). Even if there are cross-country differences, the mothers' participation rates do not return to prebirth levels in Germany, the Netherlands and the UK (Fouarge et al., 2010). Finally, the few existing studies are relatively consistent in noting that children affect mothers' career paths and nonmarket work, more than fathers'. These studies focus on the impact of the first child and devote no attention to subsequent childbirths.

We analyse the long-term inter-relations between work and family in France using a life course perspective, paying attention to both the career path and subsequent family events. Special attention is paid to the human capital of both partners, such as age and educational attainment in the process of work division throughout the lifecycle. We also analyse how educational and cultural background, i.e. the family values inherited from parents, religious feeling, ethnic origin, working history of the mothers and number of siblings, might be related to the various profiles of couples.

France is particularly interesting since it has a high maternal full-time labour force participation rate. Moreover, France is one of Europe's most fertile countries, with 2.01 children per woman on average in 2012. The quite generous and diversified family benefit system and the encouragement of early socialisation of children through nursery schools', enable various strategies regarding fertility and a range of adjustments after childbearing.

\section{Data and Method}

\subsection{Data}

The data used for this study is the "Enquête Familles et Employeurs" (Families and Employers Survey, EFE hereafter), a French nationwide representative survey conducted by INED in 2004$2005^{\mathrm{ii}}$. A sample of 9,547 individuals $(5,107$ women and 4,440 men) aged from 20 to 49 were interviewed, with a maximum of two persons per household. In total, data on 3,279 couples were gathered. This survey is one of the few in which retrospective information on family and professional life course is available for both members of couples.
Via a precise description of socio-demographic characteristics and current employment situation, the survey gives detailed information on partnership and fertility histories, i.e. the timing of cohabiting or married unions lasting at least 6 months $s^{\text {iii }}$ and of each birth ${ }^{\text {iv }}$. It also includes retrospective work histories: respondents were asked for their employment situation in every year from the age of 18. This information, taking the form of an event-history calendar, is based on the respondents' situations that have lasted at least 6 continuous months. For each spell longer than 6 months, six main types of situation are possible: employment (distinguishing between part-time and full-time work)-, unemployment, studies or training, military service, parental leave, other economic inactivity. An additional "status" was included: combination of short spells of employment or training with short spells of unemployment. For each of these seven states, the respondents were asked to point out the corresponding years of occurrence. It might be that more than one situation was identified for a given year ${ }^{v}$. As in all retrospective surveys, the answers on job and family history may be at risk of memory problems or lapses (Auriat, 1991). However, for this purpose, special care was taken in the collecting process, by limiting contents to the most basic events such as couple formation, births, moves or changes in employment status, and by linking these events with a computerised calendar to check response coherence.

\subsection{Sample selection}

As the study is intended to analyse the relationship between couple's employment situation and successive births, the couple's life course is observed over the long run. In order to take into account the significant proportion in France of couples with at least 3 children $^{\text {vi }}$ and childbearing postponements, couples in partnership for at least 15 years are selected ${ }^{\text {vii }}$. Men and women were observed over 18 years, i.e. from three years before couple formation to 15 years after viii. These long-lasting couples are specific in a context of increasing divorce and separation, but a long period is necessary to observe couple specialisation. Moreover, the longer histories are followed, the more complete fertility history we observe. A shorter duration would prevent us from examining how the work-family balance occurs after the birth 
of high-parity children. Hence, 15 years after couple formation, almost all third births within the couple are observed (i.e. 97\%) and more than $90 \%$ of the fourth births.

Our sample is made up of individuals belonging to the 1954-1968 cohort, i.e. aged from 36 to 49 in 2004. Among them, 5\% have never been in partnership and $12 \%$ have had one or more partnerships for less than 15 years. Long-lasting couples are the majority since $83 \%$ have had at least one partnership for 15 years or more: 32\% were single at the time of the survey, $16 \%$ whose partner was not surveyed ${ }^{\mathrm{ix}}$ and $35 \%$ were in partnership and we collected information for both partners. Our sample selects the latter and includes 941 cohabiting or married couples $(1,882$ individuals) $^{x}$.

Table 6 in the Appendix compares people in our sub-sample to people of the same cohort in the four different groups presented above. Of course, individuals who remain in partnership for a long time are different from individuals who do not: they form their first and current couple partnership earlier and have more children than individuals of the same cohort with shorter or no partnerships. There are small dissimilarities between those two populations regarding the distribution by educational level - they less frequently hold a university diploma - but, in terms of occupational careers, individuals in the sample have had longer periods of stable employment than the population at large, and shorter periods of unemployment, short-term jobs and inactivity. Thus, the analysis is restricted to quite stable couples, in terms of both family situation and employment profiles.

\subsection{Definition of couples' activity and parental status}

Six activity states are taken into account: studies, inactivity, unemployment, short jobs, part-time stable jobs and full-time stable jobs. Short jobs are employment spells lasting less than 6 months. Some states have been grouped together: studies and national service have been put together, since national service was entered just after the end of schooling, and also inactivity and parental leave. These states are not equally spread throughout the couples' histories (Table 1). During the union, while men spend most time in full-time stable employment, the situation is highly different for women. Full-time stable employment represents on average less than half of their life-course time, inactivity more than $20 \%$ and part-time stable employment about $13 \%$.

Concerning the parental trajectory, at the time of the survey, $4 \%$ of the couples had no child, $15 \%$ had one, $49 \%$ two, $25 \%$ three and only $8 \%$ four or more. Therefore the parental variable is coded in four dynamic states: 0 child; 1 child; 2 children; 3 children or more ${ }^{\mathrm{xi}}$.

Table 1. Percentage of time spent in the various occupational states during the union, for women and men

\begin{tabular}{lcc} 
Occupation & Women & Men \\
\hline Studies & 3.9 & 4.2 \\
Inactivity & 23.0 & 0.5 \\
Unemployment & 3.8 & 1.1 \\
Short jobs & 5.0 & 3.3 \\
Part-time stable employment & 14.2 & 1.4 \\
Full-time stable employment & 50.1 & 89.5 \\
Total & 100.0 & 100.0 \\
\hline $\mathrm{N}$ & 941 & 941
\end{tabular}




\subsection{A sequence analysis approach}

We use optimal matching analysis (OMA) to define couple trajectories. This method is based on a set of dynamic algorithms mostly used in molecular biology to study DNA strings. It was introduced into the field of social sciences by Andrew Abbott in the 1980s (Abbott \& Forrest, 1986). Since then, optimal matching has been successfully applied to life courses and family histories (Billari, 2001; Schoon, McCullough, Joshi, Wiggins \& Bynner, 2001; Aassve, Billari \& Piccarreta, 2007; Pollock, 2007) and careers (Stovel, Savage \& Bearman , 1996; Blair-Loy, 1999; Han \& Moen, 1999; Robette \& Thibault, 2008; AnyadikesDanes \& McVicar, 2010), as well as many other topics such as couples' time-schedules (Lesnard, 2010). Despite a few criticisms ( $\mathrm{Wu}, 2000$; Elzinga, 2003), it has now become widely accepted as a useful tool for life course scholars (Aisenbrey \& Fasang, 2010).

Optimal matching is based on measuring similarities between pairs of sequences. More precisely, it measures the dissimilarity between two sequences by calculating the cost of the transformation of one sequence into the other. The transformation is carried out by means of three elementary operations: insertion (one element is inserted into the sequence), deletion (one element is deleted from the sequence) and substitution (one element is replaced by another). Each elementary operation can be assigned a specific cost. A series of operations costs the equivalent of the sum of the elementary operations involved, and eventually the dissimilarity between two sequences is equal to the minimal cost of transformation of one sequence into the other. Optimal matching of each pair of sequences in the data leads to the creation of a distance matrix, which can then be used as an input for clustering or scaling techniques, for instance.

The dissimilarity measuring procedure can be illustrated by the following example. Consider two sequences of letters, e.g. two words: "family" and "marriage" (Figure 1). The transformation of "family" into "marriage" can be carried out in this way: $F$ is replaced by $M, R$ in inserted between $A$ and $M, M$ is replaced by $R, L$ by $A, Y$ by $G$ and finally $E$ is inserted at the end of the word. If substitution, insertion and deletion operations all have the same unitary cost, then matching "family" and "marriage" will cost 6: the dissimilarity between these two sequences is equal to 6 .
Figure 1. Optimal matching of "marriage" and "family"

$\begin{array}{llllllll}M & A & R & R & \text { I } & A & G & E \\ F & A & M & \text { I } & \text { L } & Y & & \\ & & & & & & & \end{array}$

The couple sequences we want to analyse can be considered as multi-dimensional: they include the woman's occupational history, the man's occupational history and the partners' parental history. This aspect requires a specific strategy. From a methodological point of view, several alternatives emerge in the life course literature based on sequence analysis (Blanchard, 2010; Gauthier, Widmer, Bucher \& Notredame, 2010). A first strategy involves first using optimal matching to compute one distance matrix for each dimension and then to carry out a linear combination of these matrices into one by means of linear combination (Han \& Moen, 1999). A second strategy involves creating a new state variable combining the single states associated to each dimension (see for instance Blair-Loy, 1999; Aassve, Billari \& Piccarreta, 2007; Pollock, 2007; Robette, 2010): for example, a combined state might be "female with a part-time job, male with a full-time job, one child". The advantage of this second alternative - the one we chose - is to take into account the interdependency of the dimensions right from the coding stage. Moreover, although the combined state variable potentially has $6 * 6 * 4=144$ states $^{\text {xii }}$ which may seem a large number, previous studies have emphasised the robustness of OMA even in cases of large state spaces (Robette, 2010).

The choice of substitution, insertion and deletion costs is an important stage in OMA - and the main problem in the application of optimal matching (Wu, 2000): it involves a trade-off between favouring the contemporaneousness of states and emphasising their order within sequences (Lesnard, 2010). As far as substitution costs are concerned, since there are no clear theoretical assumptions about the relative resemblance between states, they are set to a constant value of 2 . The insertion and deletion cost (called indel ${ }^{x i i i}$ cost) is set to slightly more than half the substitution cost (i.e. 1.1), which avoids an excessive use of indel operations and retains the information concerning the time when transitions occur (Maclndoe \& Abbott, 2004) ${ }^{\mathrm{xiv}}$. Computations 
are done with the TraMineR package in $R$ (Gabadinho, Ritschard, Müller \& Studer, 2011).

Our sequences are built from an event, i.e. couple formation. A given age, for instance 18 years old, would have been an alternative, but clusters would have been driven mostly by the duration of studies and so by educational level, which was not our main point of interest. Besides, while computing for each cluster median ages at couple formation for women and men, we observe that the variations between clusters are quite limited.

Each year, a couple's status is defined by the cross-combination of parity $(0 ; 1 ; 2 ; 3$ children or more), the woman's employment status (inactivity; unemployment; studies; part-time; short jobs; stable job) and the man's employment status (ditto). This means our approach takes into account the differences in association between fertility and employment. OMA, as we apply it, deals very well with the relationship between family and employment. It shows graphically how childbearing and women and men's employment are related, for each parity separately. So this method offers a very good description of life courses; it does not aim at understanding underlying mechanisms or establishing any causal relationship.

\section{A variety of couple histories}

From these similarities of couples' professional and family histories, an 11-cluster typology is built, using Hierarchical Cluster Analysis with Ward's criterion on the distance matrix produced by
$\mathrm{OMA}^{\mathrm{xv}}$. Table 2 summarises the main characteristics of these different clusters, according to the women's and men's activity profiles, and transitions to parenthood, and the level of intra-class dissimilarity, which indicates how heterogeneous the class is. The number of couple profiles of is quite high, reflecting the various forms of workfamily adjustment in France. None of these groups dominates clearly, showing that work-family patterns are very heterogeneous in France, in terms of both employment history and childbearing history. The two main groups are couples with 2 children and full-time employment for both partners, and the last cluster called "multiple states", the most heterogeneous one according to the intra-cluster dissimilarity index, which seems to be the remaining cluster ${ }^{x i}$ containing males and females who change professional status several times during their life course. These two groups each represent about $15 \%$ of couples.

The number of children after 15 years of union and the pace of births - i.e. quantum and tempo differ between clusters. But almost all couples have at least one child, even the most work-oriented ones. This result comes from both the fact that France remains a family-oriented country with strong parental norms and generous family policy, but also from the selection of our sample, which over-represented long-lasting couples. The few childless couples (after 15 years of life together) are almost all in the 0 or 1 postponed child cluster that represents $10 \%$ of couples. 
Table 2. 11 couple profiles

\begin{tabular}{|c|c|c|c|c|c|c|}
\hline Pattern name & $\begin{array}{l}\text { Woman's } \\
\text { activity }\end{array}$ & $\begin{array}{l}\text { Man's } \\
\text { activity }\end{array}$ & Children & $\mathbf{N}$ & $\%$ & $\begin{array}{l}\text { Heterogeneity } \\
\text { (average intra- } \\
\text { cluster } \\
\text { dissimilarity) }\end{array}$ \\
\hline Mother works full time & & & & 463 & 49.2 & \\
\hline Work-oriented, 1 child & $\begin{array}{l}\text { Stable } \\
\text { employment }\end{array}$ & $\begin{array}{l}\text { Stable } \\
\text { employment }\end{array}$ & 1 (or 2$)$ & 90 & 9.6 & 12.9 \\
\hline 0 or 1 postponed child & $\begin{array}{l}\text { Stable } \\
\text { employment }\end{array}$ & $\begin{array}{l}\text { Stable } \\
\text { employment }\end{array}$ & $\begin{array}{l}0.1 \text { or } 2 \\
\text { late }\end{array}$ & 93 & 9.9 & 16.3 \\
\hline Spaced births & $\begin{array}{l}\text { Stable } \\
\text { employment }\end{array}$ & $\begin{array}{l}\text { Stable } \\
\text { employment }\end{array}$ & 2 spaced & 71 & 7.5 & 19.2 \\
\hline $\begin{array}{l}2 \text { children and full-time } \\
\text { employment }\end{array}$ & $\begin{array}{l}\text { Stable } \\
\text { employment }\end{array}$ & $\begin{array}{l}\text { Stable } \\
\text { employment }\end{array}$ & 2 & 133 & 14.1 & 18.9 \\
\hline $\begin{array}{l}3 \text { children and full-time } \\
\text { employment }\end{array}$ & $\begin{array}{l}\text { Stable } \\
\text { employment }\end{array}$ & $\begin{array}{l}\text { Stable } \\
\text { employment }\end{array}$ & 3 or more & 76 & 8.1 & 20.7 \\
\hline Mother works part-time & & & & 121 & 12.8 & \\
\hline $\begin{array}{l}2 \text { children and part-time } \\
\text { employment }\end{array}$ & $\begin{array}{l}\text { Shift to part- } \\
\text { time }\end{array}$ & $\begin{array}{l}\text { Stable } \\
\text { employment }\end{array}$ & 2 & 67 & 7.1 & 20.1 \\
\hline $\begin{array}{l}3 \text { children and part-time } \\
\text { employment }\end{array}$ & $\begin{array}{l}\text { Shift to part- } \\
\text { time }\end{array}$ & $\begin{array}{l}\text { Stable } \\
\text { employment }\end{array}$ & 3 or more & 54 & 5.7 & 22.1 \\
\hline Shift to inactivity & & & & 209 & 22.3 & \\
\hline 1 child and inactivity & Shift to inactivity & $\begin{array}{l}\text { Stable } \\
\text { employment }\end{array}$ & 1 or 2 & 60 & 6.4 & 25.0 \\
\hline 2 children and inactivity & Shift to inactivity & $\begin{array}{l}\text { Stable } \\
\text { employment }\end{array}$ & 2 & 61 & 6.5 & 19.3 \\
\hline 3 children and inactivity & Shift to inactivity & $\begin{array}{l}\text { Stable } \\
\text { employment }\end{array}$ & 3 or more & 88 & 9.4 & 21.7 \\
\hline Multiple states & Different status & $\begin{array}{l}\text { Different } \\
\text { status }\end{array}$ & Various & 148 & 15.7 & 33.1 \\
\hline \multicolumn{4}{|l|}{ TOTAL } & 941 & 100 & \\
\hline
\end{tabular}

Source: EFE, 2004-2005.

Sample: Couples of the 1954-1968 cohort in partnership for at least 15 years

Male profiles are very homogeneous: most of them are in stable employment all along their trajectory whatever the cluster. Thus, men's occupational careers are not impacted by childbirths. This result, which suggests that men make few trade-offs for the sake of family life, is in line with studies conducted in Germany, the UK and the US (Kaufman \& Uhlenberg, 2000; Kühhirt, 2012) and confirms previous results for France (Pailhé \&
Solaz, 2006). On the other hand, female profiles are very diverse. Some women experience inactivity or part-time job spells, of varying length and/or frequency, sometimes equally spread and in other cases mostly at the beginning or at the end of the union (see tables 7 and 8 in the Appendix, which give average duration of spells and frequencies of participation). Some women stay inactive or work full-time all the time. The variety of work-family 
adjustments mainly depends on women and on strategies regarding childbearing. However, dual earners working full-time prevail: about half of couples follow this egalitarian pattern. Couples for whom full-time employment is the most continuous belong to the One child work-oriented cluster $(10 \%$ of couples). In this group, for men as for women, births do not involve any visible change in the work history. The first child is born during the first eight years but it is not followed by a second birth. Among the other full-time dual-earner clusters, a large share has at least two children.

On the other hand, some women shift to longterm inactivity (22\% of the couples) or to part-time jobs (13\%) after childbearing. Part-time usually takes place after the birth of the second child and continues thereafter. The situation is particularly frequent for two-child families or when the first three children are very close in age. However, one small but interesting cluster, called One child inactivity, is made up of couples for whom inactivity begins from, or even before, the first child. A large proportion of women in this group work for some years before couple formation but some stop working at this particular moment. Some of them face long-term unemployment at the moment of integration into the labour market and may feel discouraged and choose to invest more in family life.

The computation of median spacing between events $^{\text {xvii }}$ (Table 3), state distribution plots and index plots (see Figures 2 and 3 in the Appendix), provide more precise and original information about the timing and rhythm of family and occupational transitions. For instance, it brings to light a Spaced births cluster (7.5\% of couples). The time interval between the first two births in this cluster is noticeably larger than in the other clusters with at least two children, i.e. 6 years on average compared to 2-3 years in the other groups. Other couples postpone the birth of the first child. The first child of the couples in the 0 child or 1 postponed child cluster, if born at all, arrives very late, after more than 7 years of cohabiting union. One reason is that a significant proportion of these couples began living together while they were still students and some of them faced several spells of unemployment or short-job periods. Young people entering the French labour market face a high risk of unemployment and job insecurity, even more pronounced during an economic downturn. One way to limit the deleterious effects of reconciling motherhood and work is to deliberately limit the number of children: that is the compromise chosen by couples in the Work-oriented 1 child and 0 or 1 postponed child clusters.

More generally, a lower number of children is associated with more spaced family events, particularly in clusters with part-time jobs or inactivity. For instance, couples in the 3 children and inactivity group have their first child 1.5 years after couple formation, while those of the 2 children and inactivity group 2.1 years after and those of the 1 child and inactivity group 5.5 years after.

Lastly, the final cluster called "multiple states" contains males and females who both change professional status several times during their life course. Even when both partners have discontinuous careers, the woman's trajectory is much more discontinuous than the man's. The alternation of unemployment spells, short-term jobs and training spells even after the end of initial studies, reveals these women's strong commitment to work. As a consequence, their rhythm of family events is very similar to that of the Spaced births cluster. 
Table 3. Median duration between demographic events, by cluster (years)

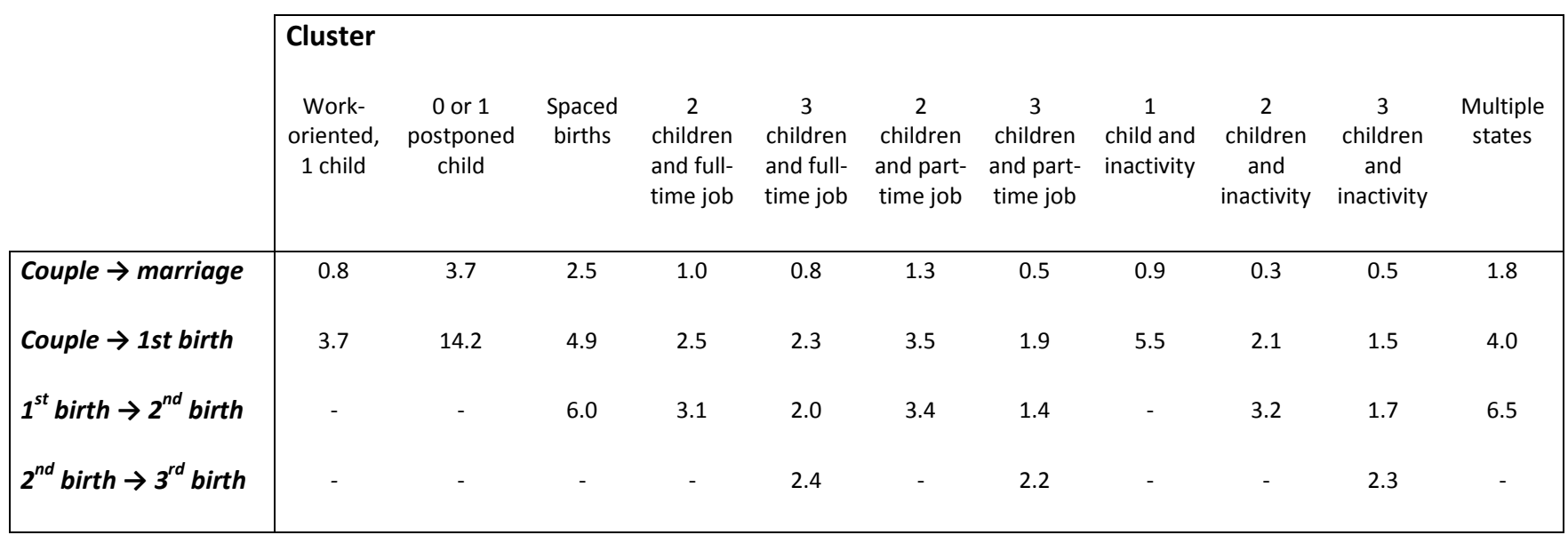

Source: EFE, 2004-2005.

Sample: Couples of the 1954-1968 cohort in partnership for at least 15 years

\section{Characteristics of various couples}

Beyond their family and employment histories, groups of couples differ in their individual and family background characteristics. These characteristics are particularly interesting because they were not included in the clustering process, and did not contribute to its building. We observe relationships between background and couples' lifecycle patterns (see the results in Tables 4 and 5). As individual and couple variables, we analyse partners' relative endowment in terms of age $\mathrm{eviii}^{\text {, }}$ level of education, age and activity status at partnership formation, and marital status. Some background variables are also introduced, since individuals may adhere to behaviour, values, and norms that dominated during their childhood, and this may affect their preferences regarding work and family. Characteristics of the family of origin include whether the respondent had at least two siblings, and an indicator of immigrant background, separating French-born from European and nonEuropean immigrants. An additional indicator of the cultural context is introduced through the individual's religiosity, i.e. if the respondent reported that religion is important in their daily life.

The two most career-oriented groups, i.e. the Work-oriented one child group and the 0 or 1 postponed child group share common traits. They both have more egalitarian and non-traditional characteristics and background. They are more likely to be non-married, to have grown up with few siblings and a working mother, especially men (the two characteristics might be linked). Women are more often older in these couples and men are much less religious. These two groups are mainly distinguished by the female level of schooling, which is higher in the 0-1 postponed child group. Women more frequently hold a tertiary level of education and their long period of studies makes them more likely to still be students at the time of couple formation.

In the two groups that combine full-time employment and a medium or high number of children, i.e. the 2 children full-time and 3 children full-time groups, women also have a heritage of continuous employment from their mothers and their mothers-in-law. Women holding a tertiary level of education are also over-represented. However, the mothers of the 3 children group display more traditional characteristics. They come from larger families, religion is more important and the age gap between partners $(M-F)$ is the highest of all clusters.

In the last career-oriented group, the spaced births group, men and women also have a weak religious feeling and a high level of education. But the men and women more often come from families where the mother never worked or interrupted her career path. Women that reconcile employment and family responsibilities through part-time work more frequently hold an intermediate level of education.

Conversely, couples where women are inactive, share both low levels of human capital and a more traditional background. Here, men and women have a low level of education. Men are more often older than their spouses, both partners' mothers have 
more frequently never worked and they are more frequently non-European immigrants, particularly women. The main difference between these 3 groups is related to their number of siblings. In particular, both men and women of the 3 children and inactivity group are more frequently born in large families.

Finally, the group multiple states includes couples where the spouses are close in age, partly because they more often met during studies. The share of highly educated is the highest and their long integration into the labour market comes from their long schooling, which implies a postponement of subsequent family stages.

From this description, it is clear that the division of labour within couples and fertility decision patterns are jointly determined by both the partners' human capital and cultural and family values. Couples' choices regarding the division of labour are mainly related to their human capital investment. In particular, people who studied for a long period are more likely to work continuously and thereby gain labour market returns on their human capital investment. So, couples in which women reconcile childbearing and work full-time with at least three children, are those with the most educated women on average. Their income probably lets them afford childcare expenses. On the other hand, couples in which the division of labour is more traditional, i.e. when the woman becomes a housewife, are those with the least educated women, given that their opportunity cost for giving up working is lower. Between these two extremes, women with an intermediate level of education more often opt for part-time. Thus, the female career path is clearly related to their level of education. ${ }^{\text {ix }}$ Education level matters less regarding the number of children born. Men's level of education is more uniform across clusters than women's, except for men whose partners stay at home, who are less educated on average, like their partners, probably due to a strong homogamy effect in the matching process.

Fertility and labour market choices are also related to family background, with a noticeable inter-generational transmission of preferences regarding work and family. Having grown up in a large family is positively correlated with family size (as shown by Booth \& Kee, 2006) since it may indicate that the respondent was raised in a family with strong family orientation (Michaël \& Tuma, 1985). However, our taxonomy shows that the relationship between the number of siblings and the number of children is mediated by the type of division of labour within the couple. For instance, couples that come from smaller families and where women opt for part-time work have more children. Other cultural aspects affect couples' trajectories. So immigrants, whose values about family and mothers' work are influenced by norms from their country of origin, are more likely to belong to the clusters with the most traditional division of labour. Religiosity is also a key determinant of the number of children and the choice of female career path.

A key factor in the couples' division of labour over the life cycle is related to the work history of respondents' mothers, i.e. whether they have been working all their life long, interrupted their career to raise their children or remained out of the labour force. An inter-generational transmission of family models and values can be seen with both their daughters', and also their daughters'-in-law division of labour ${ }^{x x}$. For instance, the cluster with the highest proportion of sons of mothers with a continuous working path, is the most work-oriented one. Similarly, the cluster with the highest proportion of housewife mothers is made up of couples where the woman's mother is a housewife as well. However, one notes a development over generations of female career paths towards stronger preference to combine work and care. For instance, sons whose mothers have never worked are more likely to belong to couples with 2 children and a part-time partner, or to those who have spaced their births. This may reflect a negotiation between partners about the division of labour in this generation, for whom the inactivity model is not the major norm any more. In the same trend of modernisation of the traditional model in the following generation, couples in which the woman is working part-time, whatever the number of children, are a little more likely to have grown up with a housewife mother. Couples with several children and a woman working part-time may probably have similar values about motherhood roles as their mothers, but they may have adapted it by reducing the number of children in order to carry on working. 
Table 4. Couple characteristics by cluster

\begin{tabular}{|c|c|c|c|c|c|c|c|c|c|c|c|c|}
\hline Cluster & $\begin{array}{l}\text { Work- } \\
\text { oriented, } \\
1 \text { child }\end{array}$ & $\begin{array}{c}0 \text { or } 1 \\
\text { postponed } \\
\text { child }\end{array}$ & $\begin{array}{l}\text { Spaced } \\
\text { births }\end{array}$ & $\begin{array}{c}2 \\
\text { children } \\
\text { and full- } \\
\text { time job }\end{array}$ & $\begin{array}{c}3 \\
\text { children } \\
\text { and full- } \\
\text { time job }\end{array}$ & $\begin{array}{c}2 \\
\text { children } \\
\text { and part- } \\
\text { time job }\end{array}$ & $\begin{array}{c}3 \\
\text { children } \\
\text { and part- } \\
\text { time job }\end{array}$ & $\begin{array}{c}1 \\
\text { child and } \\
\text { inactivity }\end{array}$ & $\begin{array}{c}2 \\
\text { children } \\
\text { and } \\
\text { inactivity }\end{array}$ & $\begin{array}{c}3 \\
\text { children } \\
\text { and } \\
\text { inactivity }\end{array}$ & $\begin{array}{c}\text { Multiple } \\
\text { States }\end{array}$ & Total \\
\hline \multicolumn{13}{|c|}{ Age gap between partners (\%) } \\
\hline Men 5 years +older & 10 & 15 & 10 & 14 & 21 & 10 & 20 & 23 & 20 & 23 & 9 & 15 \\
\hline Men 3-4 years older & 21 & 23 & 13 & 16 & 21 & 22 & 17 & 27 & 26 & 20 & 19 & 20 \\
\hline Equal age & 58 & 53 & 72 & 63 & 51 & 64 & 61 & 42 & 51 & 47 & 67 & 58 \\
\hline Women 3years + older & 11 & 10 & 5 & 7 & 7 & 2 & 2 & 8 & 3 & 11 & 6 & 7 \\
\hline \multicolumn{13}{|c|}{ Age at couple formation (median) } \\
\hline Men & 22.9 & 23.9 & 22.6 & 22.7 & 23.6 & 23.5 & 24.2 & 23.7 & 23.2 & 23,0 & 22.8 & 23.2 \\
\hline Women & 22.1 & 21.8 & 21.4 & 21.9 & 21.4 & 22.3 & 22.3 & 21.1 & 20.8 & 20.8 & 21.7 & 21.6 \\
\hline Married couples (\%) & 84.4 & 78.5 & 87.3 & 88.7 & 88.1 & 91.0 & 92.6 & 93.3 & 96.7 & 97.7 & 89.2 & 89.2 \\
\hline \multicolumn{13}{|c|}{ Men's education level (\%) } \\
\hline None or primary & 22 & 20 & 13 & 20 & 26 & 21 & 26 & 35 & 40 & 36 & 23 & 25 \\
\hline Secondary & 64 & 65 & 68 & 59 & 51 & 58 & 50 & 52 & 42 & 45 & 40 & 54 \\
\hline University & 13 & 15 & 20 & 21 & 22 & 21 & 24 & 13 & 18 & 19 & 37 & 21 \\
\hline \multicolumn{13}{|c|}{ Women's education level (\%) } \\
\hline None or primary & 26 & 19 & 18 & 26 & 19 & 19 & 15 & 43 & 48 & 45 & 26 & 27 \\
\hline Secondary & 54 & 52 & 58 & 43 & 51 & 60 & 59 & 35 & 38 & 38 & 41 & 47 \\
\hline University & 20 & 29 & 24 & 32 & 31 & 21 & 26 & 22 & 13 & 17 & 32 & 25 \\
\hline \multicolumn{13}{|c|}{ Men's employment status at couple formation (\%) } \\
\hline Working & 88 & 88 & 81 & 83 & 80 & 89 & 82 & 83 & 87 & 83 & 68 & 82 \\
\hline Unemployed & 0 & 2 & 4 & 1 & 3 & 1 & 0 & 0 & 0 & 1 & 2 & 1 \\
\hline Student & 10 & 10 & 15 & 16 & 14 & 10 & 18 & 15 & 13 & 16 & 28 & 16 \\
\hline Out of labour force & 2 & 0 & 0 & 0 & 3 & 0 & 0 & 2 & 0 & 0 & 2 & 1 \\
\hline \multicolumn{13}{|c|}{ Women's employment status at the couple formation (\%) } \\
\hline Working & 82 & 82 & 82 & 72 & 70 & 86 & 73 & 42 & 56 & 56 & 74 & 71 \\
\hline Unemployed & 2 & 1 & 1 & 4 & 1 & 1 & 7 & 13 & 7 & 4 & 3 & 4 \\
\hline Student & 13 & 17 & 13 & 20 & 26 & 9 & 18 & 8 & 11 & 12 & 18 & 16 \\
\hline Out of labour force & 3 & 0 & 4 & 4 & 3 & 4 & 2 & 37 & 26 & 28 & 5 & 9 \\
\hline
\end{tabular}




\section{Table 5. Family and cultural background by cluster}

\begin{tabular}{|c|c|c|c|c|c|c|c|c|c|c|c|c|}
\hline Cluster & $\begin{array}{l}\text { Work- } \\
\text { oriented, } \\
1 \text { child }\end{array}$ & $\begin{array}{c}0 \text { or } 1 \\
\text { postponed } \\
\text { child }\end{array}$ & $\begin{array}{c}\text { Spaced } \\
\text { births }\end{array}$ & $\begin{array}{c}2 \\
\text { children } \\
\text { and full- } \\
\text { time job }\end{array}$ & $\begin{array}{c}3 \\
\text { children } \\
\text { and full- } \\
\text { time job }\end{array}$ & $\begin{array}{c}2 \\
\text { children } \\
\text { and part- } \\
\text { time job }\end{array}$ & $\begin{array}{c}3 \\
\text { children } \\
\text { and part- } \\
\text { time job }\end{array}$ & $\begin{array}{c}1 \\
\text { child and } \\
\text { inactivity }\end{array}$ & $\begin{array}{c}2 \\
\text { children } \\
\text { and } \\
\text { inactivity }\end{array}$ & $\begin{array}{c}3 \\
\text { children } \\
\text { and } \\
\text { inactivity }\end{array}$ & $\begin{array}{l}\text { Multiple } \\
\text { States }\end{array}$ & Total \\
\hline \multicolumn{13}{|c|}{ Life cycle working status of men's mother (\%) } \\
\hline Mother always worked & 48 & 43 & 30 & 42 & 39 & 36 & 44 & 38 & 31 & 27 & 28 & 37 \\
\hline Mother occasionally worked & 20 & 18 & 20 & 20 & 13 & 12 & 9 & 17 & 16 & 14 & 22 & 17 \\
\hline Mother never worked & 32 & 39 & 49 & 35 & 45 & 48 & 43 & 43 & 51 & 55 & 46 & 43 \\
\hline Other & 0 & 0 & 1 & 3 & 3 & 4 & 4 & 2 & 2 & 5 & 5 & 3 \\
\hline \multicolumn{13}{|c|}{ Life cycle working status of women's mother (\%) } \\
\hline Mother always worked & 39 & 37 & 30 & 39 & 39 & 31 & 39 & 32 & 31 & 32 & 34 & 35 \\
\hline Mother occasionally worked & 27 & 24 & 30 & 29 & 26 & 25 & 26 & 15 & 25 & 17 & 18 & 24 \\
\hline Mother never worked & 32 & 38 & 39 & 29 & 33 & 43 & 35 & 53 & 39 & 49 & 43 & 39 \\
\hline Other & 2 & 2 & 1 & 3 & 1 & 0 & 0 & 0 & 5 & 2 & 4 & 2 \\
\hline \multicolumn{13}{|l|}{ Childhood in a large family (\%) } \\
\hline Man & 67 & 66 & 75 & 80 & 79 & 75 & 72 & 77 & 70 & 90 & 68 & 74 \\
\hline Woman & 64 & 76 & 58 & 68 & 78 & 63 & 70 & 72 & 69 & 82 & 68 & 70 \\
\hline \multicolumn{13}{|l|}{ Men's immigration status (\%) } \\
\hline Born in France & 97 & 96 & 97 & 93 & 93 & 90 & 89 & 87 & 90 & 91 & 89 & 92 \\
\hline Immigrant from Europe & 3 & 2 & 3 & 5 & 1 & 7 & 9 & 5 & 3 & 2 & 3 & 4 \\
\hline Immigrant from elsewhere & 0 & 2 & 0 & 2 & 5 & 3 & 2 & 8 & 7 & 7 & 8 & 4 \\
\hline \multicolumn{13}{|l|}{ Women's immigration status (\%) } \\
\hline Born in France & 93 & 96 & 97 & 95 & 96 & 97 & 91 & 90 & 84 & 90 & 93 & 93 \\
\hline Immigrant from Europe & 7 & 3 & 1 & 2 & 0 & 1 & 7 & 3 & 7 & 3 & 5 & 4 \\
\hline Immigrant from elsewhere & 0 & 1 & 1 & 2 & 4 & 1 & 2 & 7 & 10 & 7 & 2 & 3 \\
\hline \multicolumn{13}{|l|}{ Men's religious feeling (\%) } \\
\hline None & 42 & 40 & 41 & 36 & 33 & 31 & 30 & 27 & 10 & 28 & 41 & 34 \\
\hline Little & 37 & 32 & 37 & 35 & 37 & 36 & 30 & 32 & 48 & 26 & 34 & 35 \\
\hline Important or used to be important & 21 & 28 & 23 & 29 & 30 & 33 & 40 & 42 & 42 & 45 & 25 & 31 \\
\hline \multicolumn{13}{|l|}{ Women's religious feeling (\%) } \\
\hline None & 47 & 48 & 44 & 53 & 37 & 40 & 35 & 38 & 30 & 42 & 49 & 44 \\
\hline Little & 31 & 35 & 39 & 27 & 32 & 36 & 31 & 30 & 39 & 32 & 35 & 33 \\
\hline Important or used to be important & 21 & 17 & 17 & 21 & 32 & 24 & 33 & 32 & 31 & 26 & 16 & 23 \\
\hline
\end{tabular}




\section{Conclusion and discussion}

The sequence analysis approach (optimal matching analysis) we adopted, led to the identification of the major patterns of couples' work and family histories in France. This paper produces evidence of the effectiveness of sequence analysis in describing jointly the trajectories of both partners' work and family histories. It can be used to analyse long term effects of subsequent childbirths on male and female labour market participation.

Although the analysis is restricted to quite stable couples in terms of family and occupational trajectories, who are a specific sub-sample of the overall population, couple patterns are far from being uniform. The results show a high heterogeneity among the couples and bring to light a wide variety of work-family patterns: 11 distinct profiles are recorded. As the number of children is a key determinant of these profiles, our methodological choice of observing a long period - and therefore more completed fertility - but fewer couples rather than a shorter period and more couples, is an appropriate one. These profiles differ mainly by family size and the woman's employment trajectory, whereas that of the man is very similar between profiles, except for those with multiple states. Male careers are influenced neither by family events nor by their partners' careers. The fact that the variability of couple histories is largely more connected to women's careers and hardly at all to men's careers may moderate the contribution of the couple-level longitudinal approach adopted here. Yet its strength is that it empirically demonstrates that decisions to work less after the birth of a child are still made by women, even in a society where working mothers are usual and dual-earner couples are frequent.

More detailed information about occupational situations would probably indicate some kinds of work arrangements by men, not visible with our six-activity indicator in. However, more detailed indicators such as working hours or a subjective indicator of work investment may well be more informative but they are rarely available on a longitudinal basis, and memory bias may be more serious if they are recorded retrospectively. The small variations among men may also be driven by the selection of the observed population, and particularly by the positive correlation between a union and professional stability. Men with long-term employment are more likely to be selected for partnership, and men in long-term relationships are also more likely to be professionally stable.

The division of work within couples between market and domestic activities develops over the life cycle. Whereas the activity statuses of men and women are very similar 3 years before couple formation in every profile, they start to diverge at couple formation. They differ significantly after the birth of the first child, except in the case of workoriented couples.

However, there is no polarisation of women's profiles. In contrast to the typology of Hakim (2003) that distinguishes 3 ideal-types of women, this analysis identifies many more strategies. In particular, it shows that the sequence and timing of births seem to be endogenous to women's career preferences. Some couples prioritise their careers at some points in their life course by postponing first childbearing or spacing births. This lesser polarisation may be due to France's comprehensive family policy, which is both relatively generous and highly diverse in the tools available to help parents. This policy benefits various couple profiles, and perhaps gives more freedom in their way of balancing family and work. French parents are allowed to take parental leave on a parttime or full-time basis, and benefit from subsidised childcare and free school for children from 3, family allowances from the second child and particularly further tax reductions from the third child. However, socio-economic differences remain. In line with the standard human capital approach, partners' initial relative endowments influence couples' histories. A more traditional division of work is observed among less educated men and women, while women with greater human capital are more likely to remain employed through the transition to parenthood, whatever their partner's level of education. With the regular increase in the female level of education and permanent support to families from the State, the egalitarian model implemented by the most educated people might prevail in the future. But this effect may be attenuated by firm attitudes regarding the family, both regarding family life and the employment path. Hence, religiosity and being non-European immigrants are factors in favour of large families and focus on family life. Moreover, there is an inter-generational transmission of family models and values between mothers and daughters and daughters-in-law. One may note a shift of female career paths over generations towards a stronger preference for combining work and care. 


\section{References}

Aassve, A., Billari, F.C., \& Piccarreta, R. (2007). Strings of adulthood: a sequence analysis of young British women's work-family trajectories. European Journal of Population, 23, 369-388.

Abbott, A., \& Forrest, J. (1986). Optimal Matching Methods for Historical Sequences. Journal of Interdisciplinary History, 16, 471-494.

Aisenbrey, S., \& Fasang, A.E. (2010). New Life for Old Ideas: The "Second Wave" of Sequence Analysis Bringing the "Course" Back Into the Life Course. Sociological Methods and Research, 38, 420-462.

Anyadike-Danes, M., \& McVicar, D. (2010). My Brilliant Career: Characterizing the Early Labor Market Trajectories of British Women From Generation X. Sociological Methods and Research, 38, 482-512.

Anxo, D., Mencarini, L., Pailhé, A., Solaz, A., Tanturri, M.L., \& Flood, L. (2011). ). Gender Differences in Time Use over the Life Course in France, Italy, Sweden, and the US,, Feminist economics, 17,, 159195.Auriat, N. (1991.). Who forgets? An analysis of memory effects in a retrospective survey on migration history. European Journal of Population, 7, 311-342.

Baxter, J., Hewitt, B., \& Haynes, M. (2008). Life Course Transitions and Housework: Marriage, Parenthood, and Time on Housework. Journal of Marriage and Family, 70, 259-272.

Becker, G.S. (1965). A Theory of the Allocation of Time. The Economic Journal, 299, 493-517

Becker, P.E., \& Moen, P. (1999). Scaling Back: Dual-Earner Couples' Work-Family Strategies. Journal of Marriage and Family, 61, 995-1007.

Billari, F.C. (2001). Sequence analysis in demographic research. Canadian Studies in Population, 28, 439-458.

Blair-Loy, M. (1999). Career patterns of executive women in finance: an optimal matching analysis. The American Journal of Sociology, 104, 1346-1397.

Blanchard, P. (2010). Analyse séquentielle et carrières militantes, Report. Accessed 13th March from http://halshs.archives-ouvertes.fr/hal-00476193/

Blossfeld, H.P., \& Drobnic, S. (2001). Careers of couples in contemporary societies. A cross-national comparison of the transition from male breadwinner to dual-earner families. Oxford: Oxford University Press.

Bonke, J., Deding, M., Lausten, M., \& Stratton, L.S. (2008). Intra-Household Specialization in Housework in the United States and Denmark. Social Science Quarterly, 89, 1023-1043.

Del Boca, D., Pasqua, S., \& Pronzato, C. (2009). Motherhood and market work decisions in institutional context: a European perspective. Oxford Economic Papers, 61, 147-171.

Booth, A., \& Kee, H.J. (2006). Intergenerational transmission of fertility patterns in Britain. IZA Discussion Paper, 2437.

Chiappori, P.A. (1988). Rational Household Labor Supply. Econometrica, 56, , 63-90.

Craig, L., \& Mullan, K. (2010). Parenthood, gender and work-family time in USA, Australia, Italy, France and Denmark. Journal of Marriage and the Family, 72, 1344 - 1361.

Elzinga, C.H. (2003). Sequence similarity: a nonaligning technique. Sociological Methods and Research, 32, 329.

Fine-Davis, M., Fagnani, J., Giovannini, D., Hojgaard, L., \& Clarke, H. (2004). Fathers and mothers. Dilemmas of the work-life balance, A comparative Study in Four European Countries. Dordrecht, Boston and London: Kluwer.

Fouarge. D., Manzoni, A., Muffels, R., \& Luijkx, R. (2010). Childbirth and cohort effects on mothers' labour supply: a comparative study using life history data for Germany, the Netherlands and Great Britain. Work Employment and Society, 24, 487-507.

Gabadinho, A., Ritschard, G., Müller, N.S., \& Studer, M. (2011). Analyzing and visualizing state sequences in R with TraMineR. Journal of Statistical Software, 40, 1-37.

Gauthier, J.-A., Widmer, E.D., Bucher, P., \& Notredame, C. (2010). Multichannel sequence analysis applied to social science data. Sociological Methodology, 40, 1-38.

Goffman, E. (1977). The Arrangement between the Sexes. Theory and Society, 4, 301-331.

Gupta, S. (1999). The effects of transitions in marital status on men's performance of housework. Journal of Marriage and the Family, 61, 700-711.

Gutiérrez-Domènech, M. (2005). Employment Transitions after Motherhood in Spain. Labour, 19, $123-148$.

Han, S.-K., \& Moen, P. (1999). Clocking out: temporal patterning of retirement. American Journal of Sociology, 105, 191-236.

Hakim, C. (2003). Models of the Family in Modern Societies: Ideals and Realities. Aldershot: Ashgate.

Hynes, K., \& Clarkberg, M., (2005). Women's Employment Patterns During Early Parenthood: A Group-Based Trajectory Analysis, Journal of Marriage and Family, 67, 222-240.

Jansen, M., \& Liefbroer, A. (2006). Couples' Attitudes, Childbirth, \& the Division of Labor. Journal of Family Issues, 27, 1487-1511.

Kaufman, G., \& Uhlenberg, P. (2000). The Influence of Parenthood on Work Effort of Married Men and Women. Social Forces, 78, 931-947. 
Kühhirt, M. (2012). Childbirth and the Long-Term Division of Labour within Couples: How do Substitution, Bargaining Power, and Norms affect Parents' Time Allocation in West Germany? European Sociological Review, 28, 565-582.

Lesnard, L. (2008). Off-Scheduling within Dual-Earner Couples: An Unequal and Negative Externality for Family Time. American Journal of Sociology, 114, 447-490.

Lesnard, L. (2010). Setting Cost in Optimal Matching to Uncover Contemporaneous Socio-Temporal Patterns. Sociological Methods and Research, 38, 389-419.

Macindoe, H., \& Abbott, A. (2004). Sequence analysis and optimal matching techniques for social science data. In M. Hardy and A. Bryman (Eds.), Handbook of Data Analysis (pp. 387-406). London: Sage.

Matysiak, A. and Vignoli, D. (2009). Finding the "right moment" for the first baby to come: a comparison between Italy and Poland. MPIDR Working Papers, WP-2009-011.

Michaël R.T., \& Tuma N.B. (1985,). Entry into Marriage and Parenthood by Young Adults. Demography, 22, 515-544.

Pailhé, A., \& Solaz, A. (2006). Employment and childbearing: women bear the burden of the work-family balance. Population and Societies, 426.

Pailhé, A., \& Solaz, A. (2012). The influence of employment uncertainty on childbearing in France: A tempo or quantum effect? Demographic Research, 26, 1-40.

Pittman, J.F., \& Blanchard, D. (1996). The effects of work history and timing of marriage on the division of household labor: a life course perspective. Journal of Marriage and Family, 58, 78-90.

Pollock, G. (2007). Holistic trajectories: a study of combined employment, housing and family careers by using multiple-sequence analysis. Journal of the Royal Statistical Society, 170, 167-183.

Ravanera, Z.R., Rajulton, F. Burch, T.K., \& Le Bourdais, C. (2002). The early life courses of Canadian men: Analysis of timing and sequences of events. Canadian Studies in Population, 29, 293-312.

Regnier-Loillier, A. (2009). Does the birth of a child change the division of household tasks between partners? Population \& Societies, 461.

Robette, N. (2010). The diversity of pathways to adulthood in France: evidence from a holistic approach. Advances in life course research, 15, 89-96.

Robette, N., \& Thibault, N. (2008). Comparing qualitative harmonic analysis and optimal matching. An exploratory study of occupational trajectories. Population-E, 64, 533-556.

Schoon, I., McCullough, A., Joshi, H., Wiggins, R., \& Bynner, J. (2001). Transitions from school to work in a changing social context. Young, 9, 4-22.

Shelton, B., \& John, D. (1996). The division of household labour. Annual Review of Sociology, 22, $299-322$.

Stovel, K., Savage, M., \& Bearman, P. (1996). Ascription into achievement: models of career systems at Lloyds Bank, 1890-1970. American Journal of Sociology, 102, 358-399.

Van der Lippe, T. (1994). Spouses and their Division of Labour. Kyklos, 30, 43-62.

Vignoli, D., Drefahl, S., \& De Santis, G. (2012). Whose job instability affects the likelihood of becoming a parent in Italy? A tale of two partners. Demographic Research, 26, 41-62.

Wu, L.L. (2000). Some comments on "Sequence analysis and optimal matching methods in sociology: Review and prospect". Sociological Methods and Research, 29, 41-64. 
Appendix

Table 6. Main characteristics of people in and outside the sample, 1954-1968 cohort

\begin{tabular}{|c|c|c|c|c|c|c|}
\hline & $\begin{array}{l}\text { Sample: in } \\
\text { partnership for } \\
15 \text { years and } \\
\text { more, partner } \\
\text { surveyed }\end{array}$ & $\begin{array}{l}\text { In partnership } \\
\text { for } 15 \text { years } \\
\text { and more, } \\
\text { partner not } \\
\text { surveyed }\end{array}$ & $\begin{array}{c}\text { Not in } \\
\text { partnership, } \\
\text { past } \\
\text { partnership for } \\
15 \text { years and } \\
\text { more }\end{array}$ & $\begin{array}{c}\text { In partnership } \\
\text { for less than } 15 \\
\text { years }\end{array}$ & Always single & $\begin{array}{c}\text { Total } \\
\text { population }\end{array}$ \\
\hline Age & 42.7 & 44.3 & 44.4 & 39.9 & 41.4 & 41.9 \\
\hline Number of siblings & 3.1 & 3.7 & 3.3 & 3.1 & 3.8 & 3.3 \\
\hline Number of children & 2.2 & 2.3 & 2.4 & 1.8 & 0.2 & 2.0 \\
\hline No children & 0.04 & 0.04 & 0.05 & 0.15 & 0.89 & 0.13 \\
\hline 1 child & 0.15 & 0.16 & 0.14 & 0.25 & 0.06 & 0.18 \\
\hline 2 children & 0.49 & 0.42 & 0.41 & 0.38 & 0.04 & 0.41 \\
\hline $3+$ children & 0.33 & 0.38 & 0.40 & 0.22 & 0.02 & 0.28 \\
\hline Number of partnerships & 1.1 & 1.2 & 1.2 & 1.5 & 0.0 & 1.2 \\
\hline Age at first partnership & 22.5 & 21.2 & 21.0 & 25.4 & & 21.8 \\
\hline Age at current partnership & 22.8 & 23.5 & & 30.0 & & 24.8 \\
\hline Duration of current partnership & 20.1 & 21.0 & & 9.6 & & 12.6 \\
\hline Age at end of studies & 18.9 & 18.4 & 18.5 & 19.7 & 19.6 & 19.1 \\
\hline Unqualified & 0.17 & 0.25 & 0.23 & 0.15 & 0.28 & 0.18 \\
\hline Vocational diploma & 0.45 & 0.41 & 0.40 & 0.41 & 0.32 & 0.42 \\
\hline Secondary education & 0.14 & 0.13 & 0.15 & 0.13 & 0.12 & 0.13 \\
\hline Tertiary education & 0.23 & 0.18 & 0.20 & 0.31 & 0.27 & 0.26 \\
\hline Number of years of unemployment & 0.6 & 0.8 & 0.9 & 0.9 & 1.2 & 0.8 \\
\hline Number of years of short-term jobs & 0.9 & 1.1 & 1.3 & 1.4 & 1.6 & 1.2 \\
\hline Number of years of long-term jobs & 17.5 & 15.9 & 16.0 & 14.7 & 15.2 & 16.0 \\
\hline Number of years out of the labour force & 3.0 & 5.7 & 5.1 & 2.3 & 3.2 & 3.3 \\
\hline Number of jobs (> 6 months) & 2.7 & 2.9 & 3.1 & 3.1 & 2.9 & 2.9 \\
\hline $\mathrm{N}$ & 1882 & 889 & 1730 & 664 & 285 & 5450 \\
\hline$\%$ & 34.5 & 16.3 & 31.7 & 12.2 & 5.2 & 100.0 \\
\hline
\end{tabular}


Table 7. Description of woman's and man's activity according to couples' career typology (duration in years)

\begin{tabular}{|c|c|c|c|c|c|c|c|c|c|c|c|}
\hline & & & & & & Cluster & & & & & \\
\hline & $\begin{array}{c}\text { Work- } \\
\text { oriented, } \\
1 \text { child }\end{array}$ & $\begin{array}{c}0 \text { or } 1 \\
\text { postponed } \\
\text { child }\end{array}$ & $\begin{array}{l}\text { Spaced } \\
\text { births }\end{array}$ & $\begin{array}{c}2 \\
\text { children } \\
\text { and full- } \\
\text { time job }\end{array}$ & $\begin{array}{c}3 \\
\text { children } \\
\text { and full- } \\
\text { time job }\end{array}$ & $\begin{array}{c}2 \\
\text { children } \\
\text { and part- } \\
\text { time job }\end{array}$ & $\begin{array}{c}3 \\
\text { children } \\
\text { and part- } \\
\text { time job }\end{array}$ & $\begin{array}{c}1 \text { child } \\
\text { and } \\
\text { inactivity }\end{array}$ & $\begin{array}{c}2 \\
\text { children } \\
\text { and } \\
\text { inactivity }\end{array}$ & $\begin{array}{c}3 \\
\text { children } \\
\text { and } \\
\text { inactivity }\end{array}$ & $\begin{array}{c}\text { Multiple } \\
\text { States }\end{array}$ \\
\hline \multicolumn{12}{|l|}{$M E N$} \\
\hline inactivity & 0.1 & 0.1 & 0.0 & 0.0 & 0.0 & 0.0 & 0.0 & 0.1 & 0.0 & 0.2 & 0.3 \\
\hline unemployment & 0.1 & 0.2 & 0.2 & 0.2 & 0.2 & 0.2 & 0.1 & 0.2 & 0.2 & 0.3 & 0.3 \\
\hline studies & 1.2 & 0.8 & 1.3 & 1.6 & 1.5 & 1.1 & 1.6 & 1.3 & 1.2 & 1.6 & 2.6 \\
\hline part-time job & 0.0 & 0.1 & 0.0 & 0.1 & 0.0 & 0.0 & 0.1 & 0.1 & 0.1 & 0.1 & 1.2 \\
\hline short job & 0.3 & 0.6 & 0.4 & 0.5 & 0.7 & 0.6 & 0.4 & 0.4 & 0.5 & 0.6 & 2.0 \\
\hline stable job & 16.3 & 16.4 & 16.0 & 15.7 & 15.6 & 16.1 & 15.8 & 15.8 & 16.0 & 15.2 & 11.6 \\
\hline \multicolumn{12}{|l|}{ WOMEN } \\
\hline inactivity & 0.5 & 0.8 & 1.6 & 1.6 & 1.4 & 1.2 & 1.8 & 11.1 & 11.5 & 11.0 & 2.2 \\
\hline unemployment & 0.5 & 0.5 & 0.5 & 0.5 & 0.4 & 0.3 & 0.3 & 0.9 & 0.7 & 0.5 & 1.5 \\
\hline studies & 0.9 & 1.3 & 1.3 & 1.4 & 1.9 & 1.0 & 1.5 & 1.0 & 0.9 & 0.8 & 1.7 \\
\hline part-time job & 0.1 & 0.7 & 0.9 & 0.5 & 0.6 & 9.0 & 8.0 & 1.3 & 0.8 & 0.8 & 4.2 \\
\hline short job & 0.6 & 0.7 & 0.8 & 0.6 & 0.8 & 1.0 & 0.7 & 0.6 & 0.9 & 0.7 & 2.8 \\
\hline stable job & 15.5 & 14.1 & 12.9 & 13.4 & 12.9 & 5.5 & 5.7 & 3.2 & 3.2 & 4.2 & 5.5 \\
\hline
\end{tabular}

Table 8. Frequency of labour market participation (at least one spell)

\begin{tabular}{|c|c|c|c|c|c|c|c|c|c|c|c|}
\hline & & & & & & Cluster & & & & & \\
\hline & $\begin{array}{l}\text { Work- } \\
\text { oriented, } \\
1 \text { child }\end{array}$ & $\begin{array}{c}0 \text { or } 1 \\
\text { postponed } \\
\text { child }\end{array}$ & $\begin{array}{l}\text { Spaced } \\
\text { births }\end{array}$ & $\begin{array}{c}2 \\
\text { children } \\
\text { and full- } \\
\text { time job }\end{array}$ & $\begin{array}{c}3 \\
\text { children } \\
\text { and full- } \\
\text { time job }\end{array}$ & $\begin{array}{c}2 \\
\text { children } \\
\text { and part- } \\
\text { time job }\end{array}$ & $\begin{array}{c}3 \\
\text { children } \\
\text { and part- } \\
\text { time job }\end{array}$ & $\begin{array}{c}1 \text { child } \\
\text { and } \\
\text { inactivity }\end{array}$ & $\begin{array}{c}2 \\
\text { children } \\
\text { and } \\
\text { inactivity }\end{array}$ & $\begin{array}{c}3 \\
\text { children } \\
\text { and } \\
\text { inactivity }\end{array}$ & $\begin{array}{c}\text { Multiple } \\
\text { States }\end{array}$ \\
\hline \multicolumn{12}{|l|}{ MEN } \\
\hline inactivity & 4.4 & 5.4 & 1.4 & 1.5 & 3.9 & 1.5 & 1.9 & 5.0 & 0.0 & 10.2 & 5.4 \\
\hline unemployment & 3.3 & 9.7 & 12.7 & 10.5 & 10.5 & 11.9 & 5.6 & 10.0 & 13.1 & 17.0 & 16.9 \\
\hline studies & 61.1 & 44.1 & 57.7 & 58.6 & 59.2 & 56.7 & 55.6 & 53.3 & 60.7 & 53.4 & 68.9 \\
\hline part-time job & 0.0 & 2.2 & 0.0 & 3.8 & 2.6 & 1.5 & 5.6 & 3.3 & 6.6 & 4.5 & 14.2 \\
\hline short job & 20.0 & 25.8 & 22.5 & 27.8 & 23.7 & 29.9 & 24.1 & 18.3 & 18.0 & 29.5 & 40.5 \\
\hline stable job & 100.0 & 100.0 & 100.0 & 100.0 & 100.0 & 100.0 & 100.0 & 100.0 & 100.0 & 100.0 & 91.2 \\
\hline \multicolumn{12}{|l|}{ WOMEN } \\
\hline inactivity & 20.0 & 32.3 & 47.9 & 36.8 & 46.1 & 40.3 & 53.7 & 96.7 & 100.0 & 100.0 & 55.4 \\
\hline unemployment & 21.1 & 22.6 & 23.9 & 21.8 & 23.7 & 16.4 & 20.4 & 41.7 & 29.5 & 18.2 & 37.2 \\
\hline studies & 44.4 & 48.4 & 53.5 & 51.9 & 57.9 & 43.3 & 50.0 & 35.0 & 41.0 & 36.4 & 53.4 \\
\hline part-time job & 8.9 & 25.8 & 36.6 & 22.6 & 27.6 & 100.0 & 100.0 & 33.3 & 31.1 & 23.9 & 60.1 \\
\hline short job & 26.7 & 28.0 & 38.0 & 27.8 & 32.9 & 35.8 & 31.5 & 21.7 & 26.2 & 23.9 & 51.4 \\
\hline stable job & 100.0 & 100.0 & 100.0 & 100.0 & 100.0 & 91.0 & 90.7 & 75.0 & 88.5 & 79.5 & 85.8 \\
\hline
\end{tabular}




\section{Figure 2. State distribution plots of the typology of couples' work and family histories}

\begin{tabular}{|c|c|c|c|c|c|c|c|c|c|c|}
\hline $\begin{array}{l}\text { Work- } \\
\text { oriented, } \\
1 \text { child }\end{array}$ & $\begin{array}{c}0 \text { or } 1 \\
\text { postponed } \\
\text { child }\end{array}$ & $\begin{array}{c}\text { Spaced } \\
\text { births }\end{array}$ & $\begin{array}{c}2 \\
\text { children } \\
\text { and full- } \\
\text { time job }\end{array}$ & $\begin{array}{c}3 \\
\text { children } \\
\text { and full- } \\
\text { time job }\end{array}$ & $\begin{array}{c}2 \\
\text { children } \\
\text { and part- } \\
\text { time job }\end{array}$ & $\begin{array}{c}3 \\
\text { children } \\
\text { and part- } \\
\text { time job }\end{array}$ & $\begin{array}{c}1 \text { child } \\
\text { and } \\
\text { inactivity }\end{array}$ & $\begin{array}{c}2 \\
\text { children } \\
\text { and } \\
\text { inactivity }\end{array}$ & $\begin{array}{c}3 \\
\text { children } \\
\text { and } \\
\text { inactivity }\end{array}$ & $\begin{array}{l}\text { Multiple } \\
\text { States }\end{array}$ \\
\hline
\end{tabular}
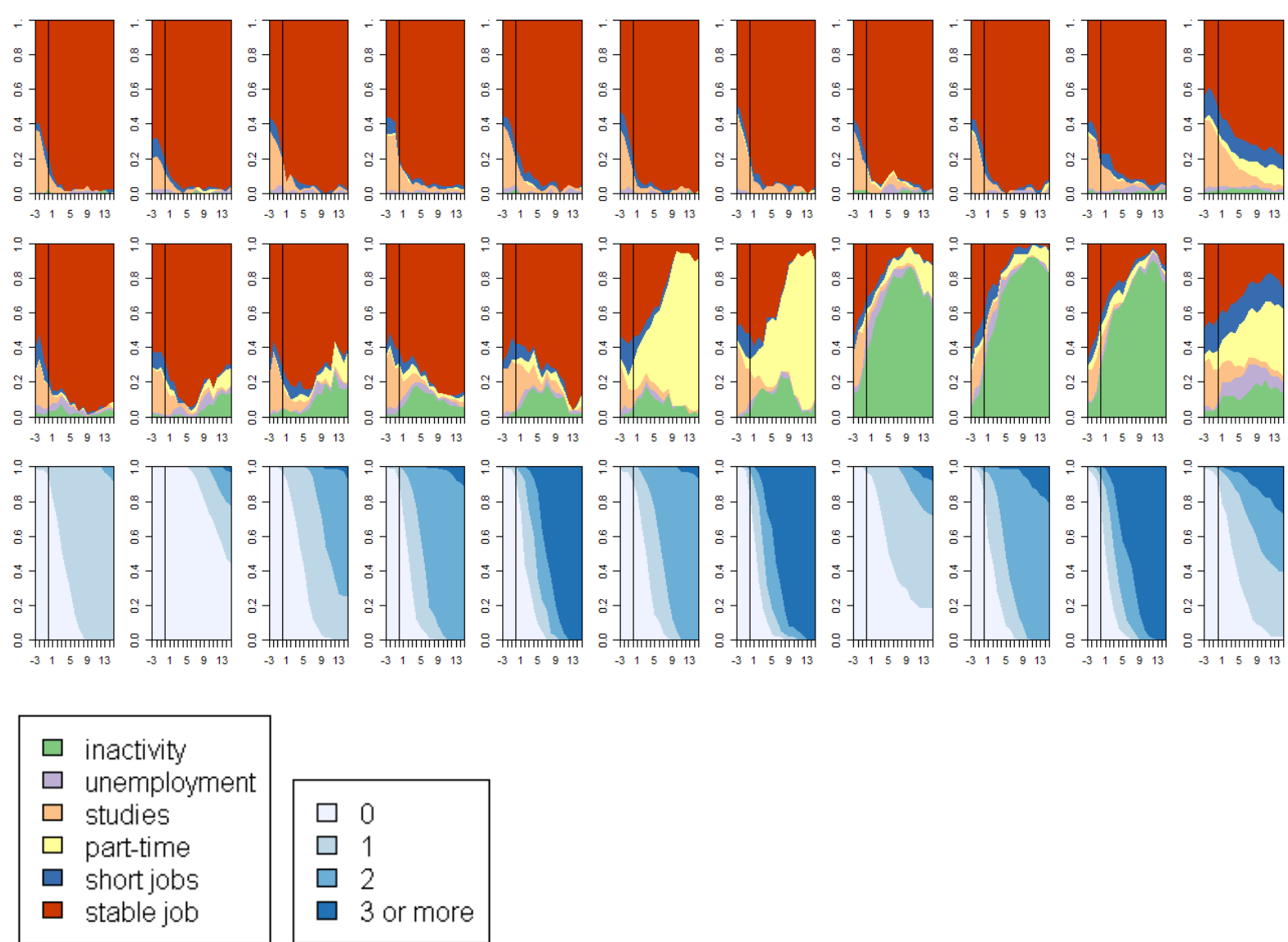

State distribution plots represent, for each cluster, each dimension of couples' life courses and any given year from 3 years before the entry into partnership to 15 years after it, the share of couples who belong to the various states. Upper panel plots stand for men's occupational careers, middle panel plots for women's careers and lower panel plots stand for couples' parental trajectories. Each cluster is represented by a column of 3 plots. Black vertical lines give the year of entry into partnership.

For instance, in the "work-oriented, 1 child" cluster (first column), 3 years before entering into partnership, about $35 \%$ of men (upper panel) are students and $60 \%$ have a stable job, while a few years later, almost all of them have a stable job. $98 \%$ of couples from this cluster are childless when they form a family, while they all have one child 8 years later. 


\section{Figure 3 - Index plots of the typology of couples' work and family histories}

\begin{tabular}{|c|c|c|c|c|c|c|c|c|c|c|}
\hline $\begin{array}{l}\text { Work- } \\
\text { oriented, } \\
1 \text { child }\end{array}$ & $\begin{array}{c}0 \text { or } 1 \\
\text { postponed } \\
\text { child }\end{array}$ & $\begin{array}{c}\text { Spaced } \\
\text { out } \\
\text { births }\end{array}$ & $\begin{array}{c}2 \\
\text { children } \\
\text { and full- } \\
\text { time job }\end{array}$ & $\begin{array}{c}3 \\
\text { children } \\
\text { and full- } \\
\text { time job }\end{array}$ & $\begin{array}{c}2 \\
\text { children } \\
\text { and part- } \\
\text { time job }\end{array}$ & $\begin{array}{c}3 \\
\text { children } \\
\text { and part- } \\
\text { time job }\end{array}$ & $\begin{array}{c}1 \text { child } \\
\text { and } \\
\text { inactivity }\end{array}$ & $\begin{array}{c}2 \\
\text { children } \\
\text { and } \\
\text { inactivity }\end{array}$ & $\begin{array}{c}3 \\
\text { children } \\
\text { and } \\
\text { inactivity }\end{array}$ & $\begin{array}{c}\text { Multiple } \\
\text { States }\end{array}$ \\
\hline
\end{tabular}

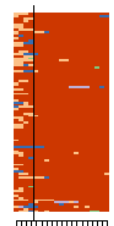

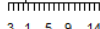

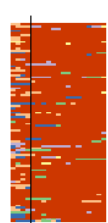

mाmाnाmाnाmा

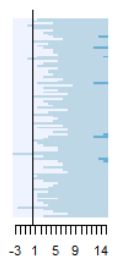

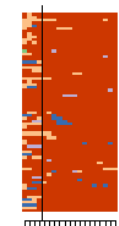

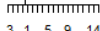

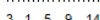

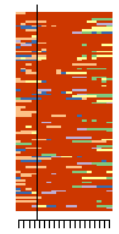

$\begin{array}{lllll}-3 & 1 & 5 & 9 & 14\end{array}$

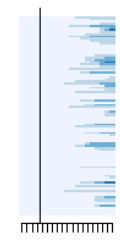

$\begin{array}{llll}-3 & 5 & 9 & 14\end{array}$
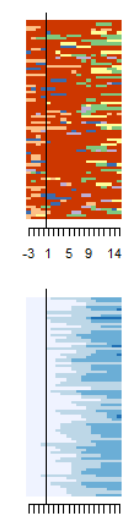

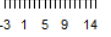

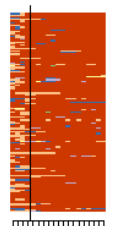

ताmाnाmाnाm

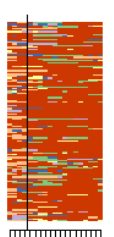

$\begin{array}{lllll}-3 & 1 & 5 & 9 & 14\end{array}$

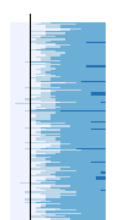

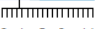

$\begin{array}{lllll}-3 & 1 & 5 & 9 & 14\end{array}$
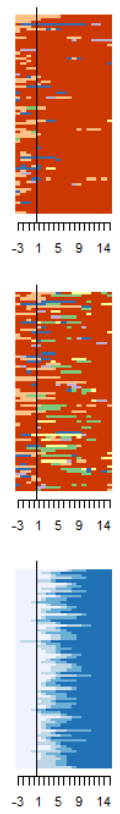

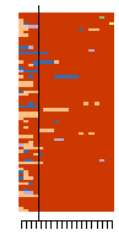

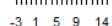
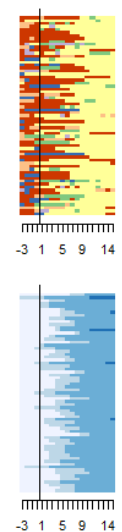

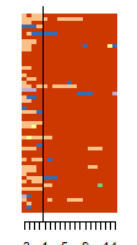

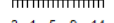
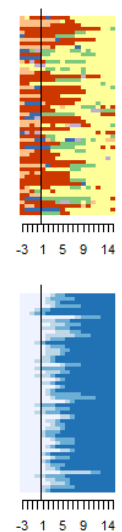

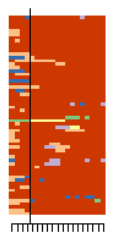

$\begin{array}{lllll}-3 & 1 & 5 & 9 & 14\end{array}$

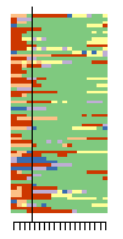

$\begin{array}{llllll}-3 & 1 & 5 & 9 & 14\end{array}$

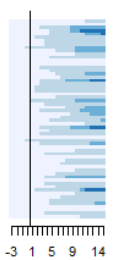

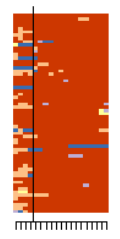

$-31159914$

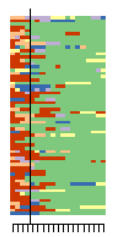

$\begin{array}{lllll}-3 & 1 & 5 & 9 & 14\end{array}$

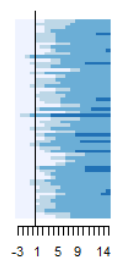

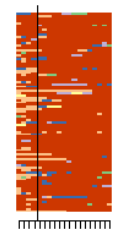

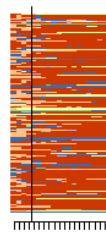

3 $159-14 \quad-31599$
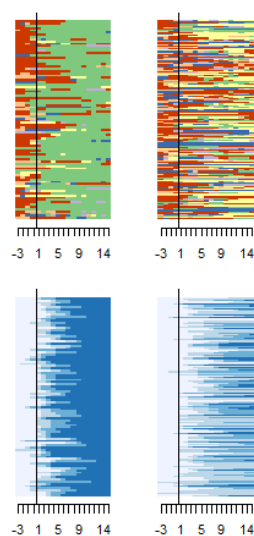

\section{$\square$ inactivity \\ $\square$ unemployment \\ $\square$ studies \\ $\square$ part-time \\ $\square$ shortjobs \\ $\square$ stable job

$\begin{array}{ll}\square & 0 \\ \square & 1 \\ \square & 2 \\ \square & 3 \text { or more }\end{array}$

In index plots, each horizontal line stands for a couple's trajectory. Each coloured segment composing the line represents a spell in a state, the length of the segment corresponding to the spell duration. As with state distribution plots, upper panel plots stand for men's occupational careers, middle panel plots for women's careers and lower panel plots stand for couples' parental trajecto ries. Each cluster is represented by a column of 3 plots. Black vertical lines give the year of entry into partnership.

For instance, in the " 3 children and part-time job" cluster (seventh column), women (middle panel) have in common to have worked part-time for a large part of the 18 years represented, although they started part-time at various periods and some of them have also had short spells of inactivity or short jobs. Almost every couple in this cluster had its first child very soon after the entry into partnership, rapidly followed by two more births. 


\section{Endnotes}

'For instance, $97 \%$ of children aged three are enrolled at pre-school, even though schooling is not compulsory at that age.

ii There are in fact two surveys, one at the individual level and one at the employer's level, the employers being those of the individuals employed at the time of the survey. Here we only use information from the individual level data and but we intend to capitalize on the matched employer-employee data in a further step.

iii Because of the retrospective frame of the survey and the risk of memory bias, only information for these at-least- 6 months partnerships were collected.

iv Including births of children who died

${ }^{\vee}$ First, some situations are not exclusive (for example, studies and unemployment); second, when a 6-month period started in year $t$ and ended in year $t+1$, the interviewers were instructed to tick both years. In that case, we have divided the year by the number of situations identified and attributed to each situation a duration equal to the corresponding proportion of year.

${ }^{v i}$ In metropolitan France, the completed fertility rate of the 1957 birth cohort is 2.14 children. Among women born in $1950,10 \%$ are childless, $20 \%$ have one child, $40 \%$ two children, $20 \%$ three children, and $10 \%$ have four or more children (Toulemon et al., 2008).

vii The duration of couple histories in our original sample varies greatly: from less than a year to 31 years with a median duration of 11 years.

viii Couples' histories are set to the same duration since optimal matching analysis remains relatively complex to implement with heterogeneity of lengths (Stovel et al., 1996).

${ }^{\text {ix }}$ The partner is not surveyed if they are out of the age range of the survey, not selected or not available to answer.

${ }^{x}$ Same-sex couples are excluded from the analysis because they were too few.

${ }^{\mathrm{xi}}$ Marital status is not included in our sequences. The reason is that, while couples who get married may differ from those who do not, the time when they get married is not of foremost importance in the study of work-family balance as compared to timing of child births. Moreover, adding a marital dimension would excessively complicate sequence analysis, by notably enlarging the number of potential states in the sequences.

xii The women's and men's occupational dimensions have 6 states and the parental one has 4 .

xiii Since inserting an element in one sequence is the same as deleting an element from the other, insertion and deletion have the same cost, which is called the indel cost.

${ }^{\text {xiv }}$ Other cost settings were tested, which led to quite convergent results.

${ }^{x v}$ The number of clusters is chosen according to a balance between parsimony on the one hand, and meaningfulness and homogeneity of clusters on the other. In this respect, summary statistics (as in Appendices 2 and 3 ) and graphical representations of clusters (Appendix 4) are helpful guidelines. Eleven is the minimal threshold to have distinct, homogeneous and substantively meaningful clusters. Divisions into fewer groups (say, 4 or 6 ) lead to one or two large 
and very heterogeneous clusters (that contain more than half of couples) and a set of small homogeneous remaining clusters, which is not satisfying.

xvi As usual, in such classification methods, one cluster (here called "multiple states") comprises all the remaining observations that do not fit into any other cluster.

xvii The median durations between couple formation and marriage are quite small. This may be due to the fact that, despite a clear definition of couple formation in the questionnaire, marriage may represent the actual time of couple formation for a large proportion of individuals.

xviii Five categories are formed: woman 5 years or more older, woman between 3 and 5 years older, partners of equal age within 2 years, man between 3 and 5 years older, man 5 years or more older. Couples do not differ much between clusters regarding the average age at union formation, which stands at around 22 for women and 23.5 for men.

${ }^{\text {xix }}$ The relationship can operate both ways, i.e. schooling choice may also be determined by priorities related to family or employment.

${ }^{x x}$ Generally, there is a correlation between mothers' and mothers-in-law's occupational status because of homogamy in the couple formation process. Almost half of women whose mother always worked match with a man whose mother worked continuously too, and the same tendency to partner similarity appears with inactive mothers. 